\title{
Impact of Financial Management Practices on SMEs Profitability with Moderating Role of Agency Cost
}

\author{
Saqib Muneer,,Rao Abrar Ahmad, Azhar Ali \\ Government College University Faisalabad, Pakistan \\ saqibmuneer85@gmail.com, *abrar_rao008@yahoo.com,rana.azharali11@gmail.com
}

\begin{abstract}
The importance of Small and medium enterprises (SMEs) towards economic development and growth is considerable. Some SMEs are facing difficulties to their development due to the lack of financial resources and management experience. The objective of this study is to check the relationships of financial management practices on profitability of small and medium enterprises and also to check the impact of agency cost on this relationship. This study consists of data analysis of two hundred SMEs from Faisalabad Pakistan. The study used primary data predominantly. SPSS 23 is used for descriptive analysis and Structural Equation Model (SEM) through Partial Least Square (PLS) 3 for hypothesis testing. The findings of this study indicate the presence of positive relationship between financial management practices and SMEs profitability but agency cost as a moderator has no effect on this relationship. The study strongly recommends higher adherence to financial management practices. Policy makers, developments partners, owners, and managers of SMEs may use these findings for sustainability of their business in Pakistan.
\end{abstract}

Keywords: Financial management practices, Agency cost, SMEs, Working Capital

\section{Introduction}

Small and medium enterprises (SMEs) have significant contribution toward creating employment and also toward the economic development and growth (International Labor Organization, 2013, p. 1; Ratten, 2014; ulHaq, Usman, Hussain, and Anjum, 2014; Karadag, 2015). In Japan, small and medium industries have marked dominance, constituting about $99 \%$ of corporations (The Information Dissemination and Policy Promotion Division of Japan's Patent Office, 2009). In South Africa, SMEs contribute about $91 \%$ of formal business and provide $61 \%$ employment opportunities and enhance the GDP of South Africa between 52 to 57 \% (Abor \& Quartey, 2010). In low income countries like Pakistan, the scale of the businesses size is limited to micro to medium. The main question is that how small and medium businesses measure their performance (Ahmad \& Harif, Hoe, 2013, p. 87; Benedict \& Matsotso, 2014, p. 247) said that failure of SMEs is inappropriate scale of measurement of the performance. The measurement of business is better through financial performance (Gallani, Krishnan \& Kajiwara, 2015, p. 6). 1). Effective use of finance much emphasized by modern research (Gitman, 2011). This scholarly effort will help to identify the financial management practices effect on the profitability of SMEs and also identify the agency cost effect. Good corporate governance is necessary for improving the performance and profitability of businesses (Braga-Alves \& Shastri, 2011; Price, Rountree \& Roman, 2011). In developing countries attention has been given to governance of the firm but still firms are suffering the governance problem (Ekanaakey, Perera \& Perera, 2010). Actually corporate governance are rules under which the relationship of manager and owner is over looked and it is make sure that the manager is working for best interest of the owner.

The contribution of this study is that financial management practices of SMEs are to improve its financial performance and review the cost that has to bear to the owner of the firm for maintaining the fair behavior of the financial manager in the best interest of the firm. SMEs are a key source of economic growth (Sadi \& Henderson, 2010), whether in developed or developing countries. In Saudi Arabia SMEs represent more than $90 \%$ of enterprises providing $51 \%$ of jobs in private sector and $22 \%$ of GDP (Mohammed, $2015 \mathrm{~b}$ ). Importance of SMEs is now widely recognized as playing a vital role in creating new jobs (OECD, 2006; Karadag, 2015). Pakistan is also a developing country and the importance of SMEs can't be ignored. Although Importance of these entities considerable but a high failure rate has found there, which led researchers to question the management practices of these entities (Fatoki, 2014, p. 922)? In Pakistan SMEs are not providing required results although when compared with other developing countries because in Pakistan SMEs are facing many problems. From the major problem lack of financial management practices also include. This study is conducted in Faisalabad city so that financial management practices adopted by SMEs and the impact of these practices on firm performance can be viewed. For this study Faisalabad is selected 
because this city is hub of the industries in Pakistan and due to this characteristic is also known as Manchester of Pakistan.

\section{Literature Review}

Pakistan located in South Asia, with population of 188 million and DGP rate 4.7 \% (The World Bank, 2015). Trade and commerce played an important role in development of the economy so that the government of Pakistan has established a body for support and promote this sector. This government body is called Small and Medium Enterprises Development Authority (SMEDA) and it has responsibility of policies making related to promotion of SMEs, facilitation of financing is also the responsibility of SMEDA. It also helps in training and educating to the entrepreneurs. Pakistan's position is lowest if it compared with other South Asian countries. The ratio of new firm in Pakistan is very low and close competitors of the firms are India and Bangladesh. Other member countries of Organization for Economic Co-operation and Development (OECD) performing much better. Specifically, United Kingdom (UK) is performing excellent and got the position at top of the ranking table. There are many factors which are badly affected performance of Pakistan businesses, and in this regard small businesses can play vital role to improve the Pakistan economy. Now Pakistan has also got memberships of OECD. In Pakistan the entrepreneurs are different from the entrepreneurs in other countries. Ali et al. (2010) has reported the impact of culture of Pakistan on entrepreneurial intentions. By using Hofstede's dimensions about cultural, the results indicate that elements of culture for instance; collectivism and uncertainty avoidance are badly affecting the thinking of entrepreneurial intentions in Pakistan.

SMEs stand for small and medium enterprises but State Bank of Pakistan (SBP) define SMEs in this way that SMEs can be classified into these three levels of business form micro enterprises, small enterprises and medium enterprises (SBP 2010). By the definition of State Bank of Pakistan SME means that any entity which is not a public limited co and has not full time employees more than 250 (manufacturing business), not more than 50 (in a trading or service business). Like other management science, financial management also establish its goals first and then its objective to achieve its financial goals. The main goal of financial management it to get maximum profit for the firm because many researchers have argued that SMEs play a significant role in the social and economic development of a country (for example, Benzing, Chu and Kara, 2009; Al-Disi, 2010; Han, Benson, Chen and Zhang, 2012; Shinozaki, 2012). Sometime financial decisions taken by owner of the firm proved wrong or wrong decision taken by the hired manager badly affect the profitability of the firm. Profitability of the firm could be damage due to the inefficient financial management. Mostly small and medium size businesses failed due to the absence of sufficient knowledge about efficient financial management. A sound financial management system has the effective governs system to the incomes, expenses, assets and liabilities to organizational performance (Abanis et al., 2013). The purpose of this study is not to cover all the aspect but only these practices will be included in this study accounting information systems, Financial Information System and working capital management.

Accounting information systems consists of bookkeeping, recoding financial activity transactions, cost accounting and the use of computers to manage these all activity. Small and medium enterprise publications and research have highlighted the importance of management of accounting system for SMEs. For example, in the literature of Lavia Lopez and Hiebl (2015) it was concluded that management of accounting system has a positive effect on performance of SMEs. Many SMEs are lower in their formal planning processes (Pemberton and Stone house, 2002). This makes relevant to examine the planning practices of small and medium businesses. Purpose of this study is to review the relationship of accounting information system toward firm profitably. Financial Information System: the frequency and the purpose of financial reporting, analysis of financial reporting, interpretation and auditing of financial reporting. Financial management expertise: the formal and informal education, relevant qualifications, training in financial management and overall financial management expertise. Working capital includes these content management of cash activity, management of account receivables and inventory management. Larger firm invested larger cash in the working capital and also have larger amounts of short term payables due to the source of financing (Deloof, 2003; Muneer et al., 2013). Both internal and external factors can influence the decision about current assets and current liabilities level. Recent studies, Silva (2011) and Gomes (2013) found positive relationship between working capital (WCM) and profitability, which indicates that firms have optimal working capital level which maximizes their profitability; see also Baños-Caballero et al. (2012) for evidence concerning with Spanish 
SME. Agency cost problem was raised by (Means and Berle, 1932) and in their research they argued that agency cost might be increased when ownership and control of the business separated. They told the cause of this increasing cost in-consistent interest of stockholders and management. Baker and Powell (2005) in their study define the agency problem as that agency problem create difficulties that are faced by the financiers to ensure the owners or stockholders of firm that their finance or fund is not wasted on any un attractive project. To check the impact of financial management practices on firm growth and role of agency cost as moderator, the following hypothesis are developed:

\section{Hypothesis 1:}

H1: Accounting information system (AIS) is positively related with profitability of SMEs.

H1a: Accounting information system (AIS) is not positively related with profitability of SMEs.

\section{Hypothesis 2:}

H2: Financial information system (FIS) is positively related with profitability of SMEs.

H2a: Financial information system (FIS) is no positively related with profitability of SMEs.

\section{Hypothesis 3:}

H3: Working capital management (WCM) is positively related with profitability of SMEs.

H3a: Working capital management is not positively related with profitability of SMEs.

\section{Hypothesis 4:}

H4: Agency Cost as a moderator is affecting the profitability of SMEs.

H4a: Agency Cost as a moderator is not affecting the profitability of SMEs

\section{Figure 1: Theoretical Frame Work:}

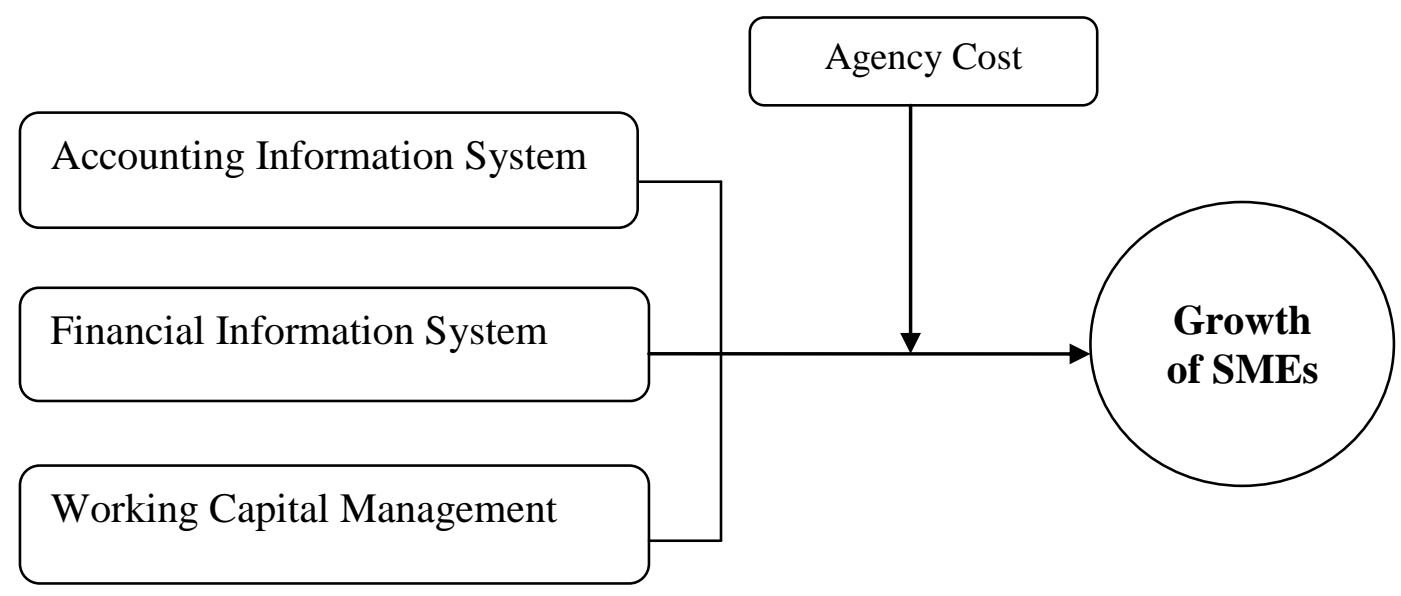

\section{Methodology}

This study occupied primary data to analyze the results from financial management practices adopted by SMEs in Faisalabad. This study is conducted to test hypothesis and to develop a relationship between the dependent variable "Firm Growth" and the independent variables "Accounting information system, Financial information system, Working capital management" with moderating effect of agency cost. Survey questionnaires are used to collect the response from the target population. The sample for this study is comprised of 300 SMEs operating in Faisalabad city. Total three hundred questionnaires were delivered to the SMEs out of which two hundred responses were received back. During data entry, 20 questionnaires were incomplete and considered as redundant. Remaining 180 questionnaires were considered for the analysis. To test the hypothesis, Structural Equation Modeling (SEM) is applied by using partial least square (PLS. 3).

\section{Results}

For the assessment of validity and reliability Cronbach's alpha, composite reliability and average variance extracted (AVE) are used in the present study. According to George and Mallery (2003) "The value of 
Cronbach's alpha less than 0.50 is not acceptable, $0.50-0.60$ is considered as poor but acceptable, while any value above 0.70 is considered as good". Results show that data is valid.

Table 1: Convergent validity (Measurement Model Quality Criteria)

\begin{tabular}{llll}
\hline & Cronbach's Alpha & $\begin{array}{l}\text { Composite } \\
\text { Reliability }\end{array}$ & AVE \\
\hline Accounting information system & 0.875133 & 0.906144 & 0.618016 \\
Financial information system & 0.768943 & 0.831819 & 0.589577 \\
Working capital management & 0.772320 & 0.828675 & 0.631078 \\
Agency cost & 0.674158 & 0.779471 & 0.618230 \\
Firm performance & 0.552810 & 0.653952 & 0.565824 \\
\hline
\end{tabular}

Financial Management Practices and Firm Performance Structural Model: Firm performance (FP) was assessed by using a three items scale. Three parameters (Accounting information system (Q1=.515), Financial information system $(\mathrm{Q} 2=.238)$ and Working capital management $(\mathrm{Q} 3=.112)$ were used to determine the firm performance and these parameters defined $(Q 5=.654)$ of firm performance overall. Its mean there were also some other variables effecting firm performance.

Figure 2: Predictive Relevance of Structural Models

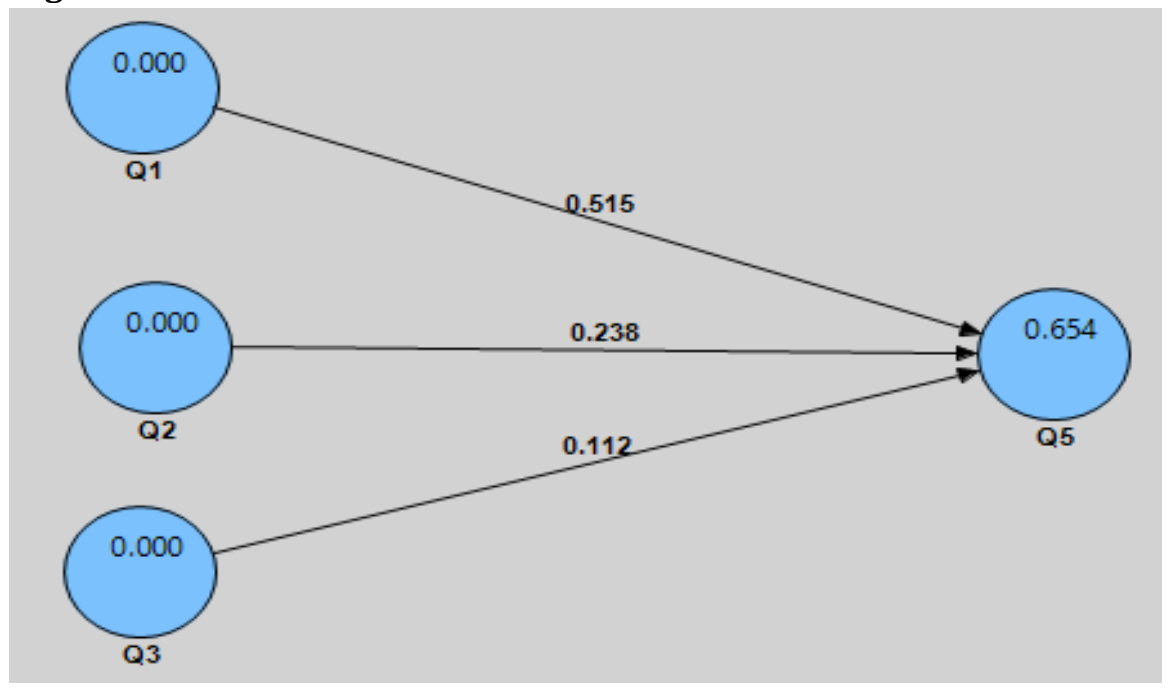

Note: Q1: Accounting information system (AIS), Q2: Financial information system (FIS), Q3: Working capital management (WCM), Q4: Agency cost, Q5 Firm performance

Table 2: Model Summery of All Independent Variables

\begin{tabular}{lllll}
\hline $\begin{array}{l}\text { Hypothetical } \\
\text { relationship }\end{array}$ & Path coefficient & $\begin{array}{l}\text { Absolute t- } \\
\text { statistical values }\end{array}$ & Values of R2 & Values of Q2 \\
\hline Q1 - Q5 & $0.515^{* * *}$ & 6.402 & & \\
$\mathbf{Q 2 - 0 5}$ & $0.238^{* * *}$ & 2.882 & & \\
Q3-Q5 & $0.112^{* *}$ & 1.979 & & \\
$\mathbf{Q 5}$ & & & 0.654 & 0.231 \\
\hline
\end{tabular}


Agency Cost (Moderator) and Firm Performance Structural Model: Agency cost is the moderator in this study. In below model agency cost (Q4) is taken as an independent variable (IV) to check its impact on firm performance and its shows $\left(\mathrm{R}^{2}=-.076,0.191,0.216\right)$ of firm performance which is very low of total firm performance. The value of $\mathrm{R}^{2}$ is not significant because it should be more than 0.5Cronbach's (1951).

Figure 3: Predictive Relevance of Structure

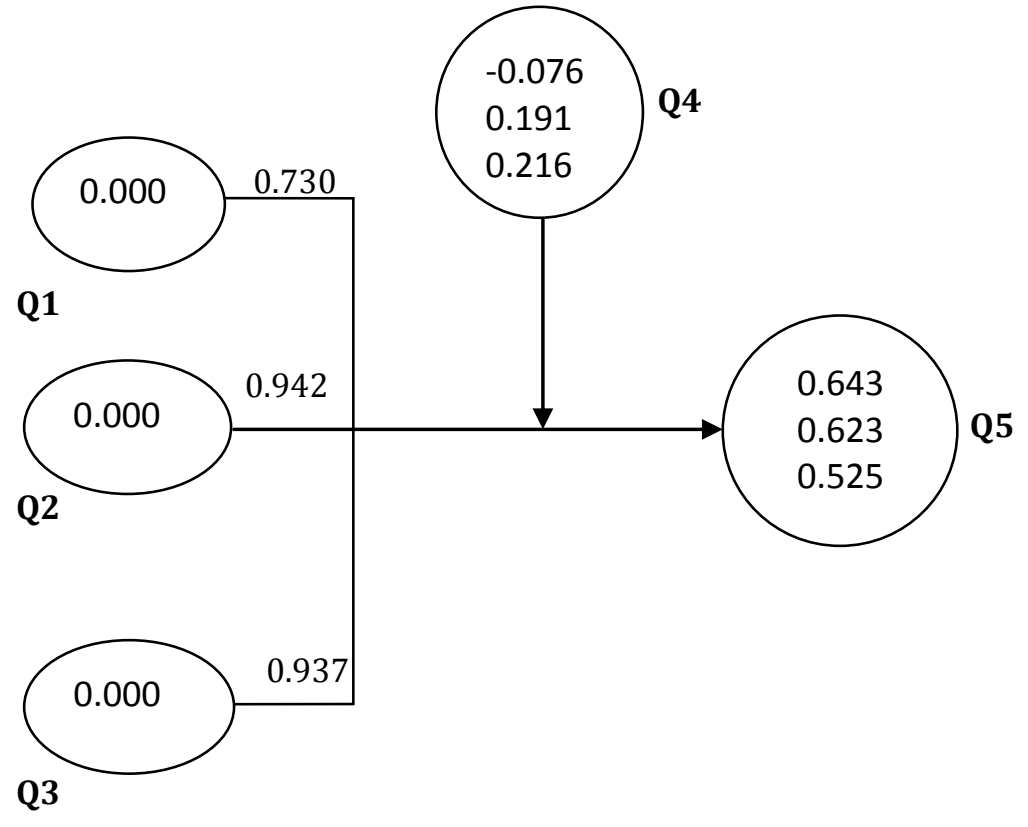

Table 3: Model Summery

\begin{tabular}{lllll}
\hline $\begin{array}{l}\text { Hypothetical } \\
\text { Relationship }\end{array}$ & Path Coefficient & $\begin{array}{l}\text { Absolute } \boldsymbol{t} \text { - } \\
\text { statistic value }\end{array}$ & Value of R2 & Moderator \\
\hline Q1-Q4 & -0.076 & 0.730 & 0.643 & Not moderator \\
Q6 & 0.191 & 0.942 & 0.623 & Not moderator \\
Q2-Q4 & & 0.937 & 0.525 & Not moderator \\
Q6 & 0.216 & & & \\
Q3-Q4 & & &
\end{tabular}

In the current study 4 hypothesis were tested. At the end results identified that 3 hypothesis (H1, H2, H3) were supported. It means results shown that AIS (accounting information system) FIS (financial information system) and WCM (working capital management) have significant impact on the profitability of SMEs. When one hypothesis was supported (H4a). It means result shown that agency cost is not affecting the relationship of (IV) and (DV) as a moderator in this study held in Faisalabad Pakistan.

\section{Conclusion}

The major objective of this study was to examine the effect of financial management practices on the profitability of small and medium business and to check the financial practices adopted by SMEs in Faisalabad city of Pakistan. The data analysis shows that financial management practices have significant impact of SMEs profitability. Most of the firms in Faisalabad city prepared their financial statement, balance sheet and income statement prepared regularly and frequently. Most of the firms have employed accountant for managing accounts department. Tendency to use computer for accounting information system was low in small size business but in medium size businesses accounting system was strong. $80 \%$ of the total firms followed cash management practices which include cash budget, review of cash budget on monthly or weekly basis. Most of the small enterprises prepare cash budget on weekly basis. This research shows that mostly firms are familiar to cash budgeting, cash control and cash flows. $36 \%$ firm face cash shortage problem for its expenditure 
while $64 \%$ firms face cash surplus. Finding tells that cash surplus is major problem than cash shortage for SMEs. Major issues created form cash surplus is that where surplus should invest for earn profit. Most of the firms have not better option to invest surplus cash in a profitable project. Agency problem may play a significance role in performance of business for this purpose present study was also examined the agency cost behaviors as a moderate between the relationship of financial management and SME profitability in Faisalabad Pakistan. But it was viewed that agency cost worked as a moderator in any other economy but not worked in Faisalabad Pakistan. This study also explains that agency cost as an independent variable have some effect on profitability of SMEs.

Limitations of the Research Study: Major limitation related to this study was financial and non-financial resources; time limitation and due to these limitation and scope of the study research have to limit the number of objectives. There are multiple areas of financial management related to research problem and research question directly or indirectly but due to the limitation of time and fund all the areas of financial management could not be investigated. Because resources were scarce so that all the SMEs in Pakistan could not be studied and selected SMEs in Faisalabad city were taken as a target population. Mostly selected firm were manufacturing concern. In Faisalabad city there are large no of small and medium business units and have different management practices and knowledge if compared with the SMEs situated in other cities of Pakistan. All primary data was collected from personal interview but failed to collect any documentary prove related provided information by the respondent. This study viewed the interval factor which influence the profitability but not viewed any external factor which may affect the financial management practices.

Implications for the Further Research: This study leads to the suggestion that in further research work should supplemented so that other areas could be examined which could not covered by this study. Following are the further suggestion for future research.

- Findings or current study can be used in other financial management practices such as management of current assets, management of fixed assets and capital structure management in other cities of Pakistan.

- Model of this study can be used in the other cities of Pakistan to check the financial management practices.

- Most of the small enterprises in Faisalabad Pakistan are not adopting better financial management practices the reasons can be reviewed.

- The financial performance of small enterprises and the medium enterprises can be viewed because there is difference in financial management practices of small enterprises and medium enterprises.

- In small enterprises owner himself manage financial activities and in medium enterprises accounts manger manage financial activities so that effect of owner and manager financial management practices can be viewed.

Finding can be used for the improvement of financial management practices especially in small enterprises for development of this sector of Pakistan.

\section{References}

Abanis, T., Sunday, A., Burani, A. \& Eliabu, B. (2013). Financial management practices in small and medium enterprises in selected districts in Western Uganda. Research Journal of Finance and Accounting, 4(2), 29-42

Abor, J. \& Quartey, P. (2010) Issues in SME Development in Ghana and South AfricaADB.2002. SME Financing: International Best Practices. Appendix-Y, May 2002 Forum. http://www.adb.org

Ahmad, K. (2014). The adoption of Management accounting practices in Malaysian Small and Medium-sized Enterprises. Asian Social Science, 10(2), 236-249.

Al-Disi, E. O. (2010). Developmental role for Waqf to support entrepreneurship and small and medium enterprises. Dubai International conference for Awqaf.

Ali, I., Ayse, K. Y., Jawaria, F. A. \& Hasan, A. (2010). Effects of national culture on entrepreneurial intentions, Business Transformation through Innovation and Knowledge Management: (Accessed 18 January, 2015). 
Baker, H. K. \& Powell, G. E. (2005). How corporate managers view dividend policy? Quarterly Journal of Business and Economics, 38(2), 17-27.

Baños-Caballero, S., García-Teruel, P. J. \& Martínez-Solano, P. (2012). How does working capital management affect the profitability of Spanish SMEs? Small Business Economics, 39, 517-529.

Benzing, C., Chu, H. M. \& Kara, O. (2009). Entrepreneurs in Turkey: A factor analysis of motivations, success factors, and problems. Journal of Small Business Management, 47(1), 58-91.

Berle, A. A. \& Means, G. (1932). The modern corporation and private properly. New York: Macmillan

Braga-Alves, M. V. \& Shastri, K. (2011). Corporate governance, valuation, and performance: Evidence from a voluntary market reform in Brazil. Financial Management, 40(1), 139-157

Deloof, M. (2003). Does Working Capital Management Affect Profitability of Belgian Firms? Journal of Business Finance \& Accounting, 30, 573-87.

Ekanayake, A., Perera, H. \& Perera, S. (2010). Contextual relativity of the role of accounting in corporate governance: evidence from the banking industry in Sri Lanka the Sixth Asia Pacific Interdisciplinary Research in Accounting Conference, Sydney, pp. 1-27

Fatoki, 0. (2014). The Causes of the Failure of New Small and Medium Enterprises in South Africa, Mediterranean Journal of Social Sciences, 5(20), 922-927.

Gallani, S., Krishnan, R. \& Kajiwara, T. (2015). Is Mandatory Nonfinancial Performance Measurement Beneficial? Accessed on 12 December 2015

George, D. \& Mallery, P. (2003). SPSS for Windows step by step: A simple guide and reference. 11.0 update (4th Ed.). Boston: Allyn \& Bacon.

Gitman, L. (2011). Principles of Managerial Finance.10th Ed., Addison, Wesley Publishing, 2003, ISBN 0-20178479-3.

Gomes, D. F. N. (2013). How does Working Capital Management affect Firms' Profitability? Evidence from Portugal, Master's thesis, Lisboa School of Economics \& Management, Portugal.

Han, L., Benson, A., Chen, J. J. \& Zhang, S. (2012). The use and impacts of bank support on UK small and medium-sized enterprises. International Small Business Journal, 1(2).

Harif, M. M., Hoe, C. H. \& Ahmad, M. I. (2013). The Financial and Non-Financial Performance Indicators of Paddy Farmers' Organizations in Kedah. World Review of Business Research, 3(1), 80-102.

International Labor Organization. (2013). Is small still beautiful? Available at: Accessed on 12 December 2015. Problems and Perspectives in Management, 14(2), 2016

Karadag, H. (2015). Financial Management Challenges In Small And Medium-Sized Enterprises: A Strategic Management Approach. EMAJ: Emerging Markets Journal, 5(1), 26-40.

Lavia-Lopez, O. \& Hiebl, M. R. W. (2015). Management accounting in small and medium sized enterprises: current knowledge and avenues for further research. Journal of Management Accounting Research, 27(1), 81-119.

Matsotso, M. L. \& Benedict, H. O. (2014). Non-Financial Performance Measures in Small Medium Enterprises' Supply Chain Management. Journal of Economics, 5(3), 247-257.

Mohammed, A. Q. (2015 b). Employee recruitment, selection and retention in Saudi Arabian family owned Small and Medium Scale Enterprises (SMEs) Kuwait Chapter of Arabian Journal of Business and Management Review, 4(6), February.2015.

Muneer, S., Rehman, S. U. \& Butt, B. Z. (2013). Dividend Signaling Power on Organizations' Future Earnings: A Brief Review of Dividend Theories. Actual Problems of Economics, 3(141), 380-387

Muneer, S., Bajuri, N. H. \& Rehman, S. U. (2013). Moderating Effect of Agency Cost on the Relationship between Capital Structure, Dividend Policy and Organization Performance: A Brief Literature Review. Actual Problems of Economics, 11(149), 434-442.

Musah, A. \& Ibrahim, M. (2014). Record keeping and the Bottom Line: Exploring the relationship between Record Keeping and Business Performance among Small and Medium Enterprises (SMEs) in the Tamale Metropolis of Ghana. Research Journal on Finance and Accounting, 5(2), 107-117.

OECD. (2006). Financing SMEs and Entrepreneurs 2006

Price, R., Román, F. J. \& Rountree, B. (2011). The impact of governance reform on performance and transparency. Journal of Financial Economics, 99(1), 76-96.

Shinozaki, S. (2012). A New Regime of SME Finance in Emerging Asia: Empowering Growth Oriented SMEs to Build Resilient National Economies: Asian Development Bank. 
Silva, S. M. S. F. N. (2011). Effects of working capital management on the profitability of Portuguese manufacturing firms, Master's thesis, Universidad do Minho, Portugal

Stonehouse, G. \& Pemberton, J. (2002). Strategic planning in SMEs - some empirical findings. Management Decision, 40(9), 853-861.

UlHaq, M., Usman, M., Hussain, N. \& Anjum, Z. (2014). Entrepreneurial activity in China and Pakistan: A GEM data evidence. Journal of Entrepreneurship in Emerging Economies, 6(2), 179-193.

Vanessa, R. (2014). Encouraging collaborative entrepreneurship in developing countries: the current challenges and a research agenda. Journal of Entrepreneurship in Emerging Economies, 6(3), 298 308. 